\title{
Pengaruh Konsentrasi Peroksida Terhadap Produksi Biohidrogen Dari Limbah Buah Jeruk Melalui Metode Fermentasi Gelap
}

\author{
Atika Dwi Farini' ${ }^{1}$, Sarto $^{2}$, Suryo Purwono ${ }^{3}$ \\ ${ }^{1)}$ Magister Teknik Pengendalian Pencemaran Lingkungan \\ 2) ${ }^{3)}$ Jurusan Teknik Kimia Universitas Gadjah Mada \\ E-mail: atikafarini@gmail.com
}

\begin{abstract}
Abstrak
Proses fermentasi gelap (dark fermentation) memiliki beberapa kelebihan, yaitu dapat memproduksi gas hidrogen tanpa membutuhkan cahaya matahari, substrat yang digunakan bervariasi dan tidak membutuhkan biaya yang besar. Upaya untuk dapat menghasilkan gas hidrogen yang tinggi, salah satunya dengan merekayasa jalur metabolisme melalui penambahan agen radikal bebas yaitu hidrogen peroksida $\left(\mathrm{H}_{2} \mathrm{O}_{2}\right)$. Penelitian ini bertujuan untuk mengetahui pengaruh penambahan $\mathrm{H}_{2} \mathrm{O}_{2}$ pada inokulum campuran dari digester biogas dengan limbah buah jeruk sebagai substrat terhadap produksi hidrogen. Hidrogen peroksida dengan konsentrasi berbeda $(0 \mathrm{mM}, 0,2 \mathrm{mM}, 0,4 \mathrm{mM}$, 0,6mM, 0,8 mM) ditambahkan ke dalam fermentor (100mL) yang telah berisi inokulum campuran dan limbah buah jeruk. Penelitian dilakukan selama 7 hari pada kondisi anaerob dengan suhu $37^{\circ} \mathrm{C}$. Hasil penelitian menunjukkan bahwa penambahan hidrogen peroksida memberikan pengaruh yang cukup signifikan terhadap produksi hidrogen dibandingkan dengan tanpa penambahan hidrogen peroksida. Produksi tertinggi gas hidrogen dihasilkan pada penambahan $\mathrm{H}_{2} \mathrm{O}_{2}$ 0,6 Mm dengan yield 801,14 ml.g/VS. Selama proses fermentasi, Volatile Fatty Acid (VFA) yang dihasilkan yaitu asam asetat, yang dapat mempengaruhi produksi gas hidrogen. Dari hasil penelitian dapat diketahui bahwa apabila dihasilkan asam asetat yang tinggi, maka dapat menurunkan produksi hidrogen.
\end{abstract}

Kata kunci : fermentasi gelap, hidrogen, hidrogen peroksida, VFA

\begin{abstract}
The process of dark fermentation (dark fermentation) has several advantages, including being able to produce hydrogen gas without the need for sunlight, the substrate used varies and does not require a large cost. Efforts to produce high hydrogen gas, one of which is by engineering metabolic pathways through the addition of free radical agents, namely hydrogen peroxide (H2O2). This study aims to determine the effect of adding hydrogen peroxide (H2O2) to the mixed inoculum of the biogas digester with orange fruit waste as a substrate on hydrogen production. Hydrogen peroxide with different concentrations $(0 \mathrm{mM}, 0.2 \mathrm{mM}, 0.4 \mathrm{mM}, 0.6 \mathrm{mM}, 0.8 \mathrm{mM})$ was added to the fermentor $(100 \mathrm{~mL})$ which contained mixed inoculums and citrus fruit waste. The study was conducted for 7 days under anaerobic conditions at 370C. The results showed that the addition of hydrogen peroxide had a significant effect on hydrogen production compared to without the addition of hydrogen peroxide, so the addition of hydrogen peroxide at certain concentrations indicated an increase in hydrogen production. The highest production of hydrogen gas is produced at the addition of $0.6 \mathrm{Mm} H 2 \mathrm{O} 2$ with a yield of $801.14 \mathrm{ml.g} / \mathrm{VS}$. During the fermentation process, Volatile Fatty Acid (VFA) produced is acetic acid that can affect the production of hydrogen gas. From the results of the study it can be seen that if high acetic acid is produced, it can reduce hydrogen production.
\end{abstract}

Keywords: dark fermentation, hydrogen, hydrogen peroxide, VFA

Dikirim/submitted: 16 Mei 2019

Diterima/accepted: 24 Mei 2019 


\section{PENDAhuluan}

Berbagai bahan bakar alternatif telah diusulkan untuk dapat menggantikan bahan bakar fosil. Dalam hal ini, hidrogen diakui sebagai salah satu bahan bakar alternatif yang menjanjikan di masa depan. Hal ini dikarenakan hidrogen merupakan gas yang ramah lingkungan, dimana hanya menghasilkan air ketika dibakar dan memiliki nilai kalori yang lebih tinggi (122 kJ/g), 2,75 kali lipat lebih tinggi dari pada bahan bakar hidrokarbon (Chang dkk., 2004 dan Kim dkk., 2006). Produksi utama hidrogen yaitu berasal dari gas alam, elektrolisis air, steam reforming hydrocarbon dan proses auto-termal, akan tetapi metode ini memerlukan biaya yang cukup banyak dan membutuhkan energi yang tinggi.

Produksi hidrogen secara biologi dengan memanfaatkan limbah untuk menghasilkan energi bersih membuat produksi hidrogen dengan metode ini lebih menjanjikan karena memiliki keuntungan yang signifikan dibandingkan dengan metode kimia, salah satunya dengan menggunakan metode fermentasi gelap. Kelebihan yang dimiliki dalam proses ini misalnya dapat memproduksi $\mathrm{H}_{2}$ tanpa membutuhkan cahaya matahari, substrat yang digunakan bervariasi dan tidak membutuhkan biaya besar (Das dkk., 2008). Selain itu, melalui proses fermentasi gelap yield hidrogen yang dihasilkan akan lebih tinggi dari yang dihasilkan oleh proses fermentasi terang dan operasinya juga lebih mudah (Elsharnouby dkk., 2013).

Dalam konversi bahan-bahan organik menjadi hidrogen melalui fermentasi gelap (dark fermentation), salah satu substrat yang dapat dimanfaatkan yaitu sludge dari hasil produksi biogas. Substrat berbasis karbohidrat merupakan substrat yang paling baik, karena dapat menghasilkan yield hidrogen yang tinggi (Kim dkk., 2010). Akan tetapi, dalam prakteknya, terdapat hambatan berupa yield hidrogen yang rendah (dikarenakan terbentuknya biomassa, asam organik, dan gas $\mathrm{CO}_{2}$ ) dan juga kecepatan pembentukan hidrogen yang rendah (Kapdan dkk., 2006). Keberhasilan dari proses fermentasi sangat bergantung pada karakteristik substrat bahan organik yang digunakan. Berbagai jenis komponen bahan organik termasuk lipid, protein dan karbohidrat dilaporkan dapat dicerna oleh bakteri penghasil $\mathrm{H}_{2}$ (Husin dkk., 2014).

Untuk dapat menghilangkan hambatan di dalam produksi gas hidrogen, salah satunya dengan cara merekayasa jalur metabolisme melalui penambahan agen radikal bebas yaitu hidrogen peroksida. 
Sehingga diharapkan dengan adanya penambahan hidrogen peroksida dapat meningkatkan produksi gas hidrogen.

\section{METODE PENELITIAN}

\subsection{Bahan}

Mikroorganisme yang digunakan dalam penelitian ini adalah konsorsium alami yang diperoleh dari 3 digester biogas berbeda, yakni instalasi pengolahan limbah buah (Pasar Buah Gamping, Yogyakarta), digester biogas kotoran sapi (peternak sapi di daerah Umbulharjo, Cangkringan, Sleman), dan digester biogas limbah tahu (pengrajin tahu di desa Gunung Saren, Srandakan, Bantul). Limbah buah jeruk yang digunakan diperoleh dari Pasar Buah Gemah Ripah, Gamping, Yogyakarta.

\subsection{Alat}

Alat-alat yang digunakan meliputi, botol vial, fermentor sistem batch, chreamper, pipet mikro dan tips, inkubator, botol serum $100 \mathrm{~mL}$, seal aluminium, syringe, tabung ependof $5 \mathrm{ml}$, gas nitrogen, autoclave, Gas Chromatography (GC), serta peralatan gelas dan lainnya yang digunakan dalam laboratorium kimia.

\subsection{Metode Penelitian}

\section{- Pre-treatment Kultur Mikroba Campuran}

Kultur mikroba campuran (kotoran sapi, limbah buah dan limbah tahu) diambil dari digester biogas. Masing-masing kultur mikroba campuran terlebih dahulu masuk dalam tahap pretreatment sebelum digunakan sebagai inokulum untuk fermentasi. Proses pretreatment berfungsi untuk menonaktifkan bakteri metanogenik yang bersifat menggunakan $\mathrm{H}_{2}$ untuk membentuk gas metana.

Mikroba methanogenik tidak dapat tumbuh pada $\mathrm{pH}$ yang rendah dibawah $\mathrm{pH}$ 5. Metode yang digunakan adalah penambahan $\mathrm{HCl} 2 \mathrm{M}$ ke dalam inokulum sampah buah hingga pH 3 selama 24 jam. Setelah proses tersebut selesai, selanjutnya $\mathrm{pH}$ dinaikkan kembali menjadi sekitar 4,5-5 dengan menambahkan $\mathrm{NaOH} 2 \mathrm{M}$.

\section{- Medium Pengkayaan Kultur Mikroba Campuran}

Pembuatan medium pengkayaan bertingkat bertujuan untuk mendapatkan kultur mikrobia campuran yang bersifat stabil. Fermentor yang digunakan ukuran 100ml dengan volume kerja 50 
$\mathrm{ml}$. Volume kerja terdiri dari $45 \mathrm{ml}$ larutan nutrisi dan $5 \mathrm{ml}$ inokulum mikroba campuran yang telah diberi perlakuan pre-treatment. Medium pengkayaan menggunakan PYG (pepton-yeastglucosa) yang mengandung nutrisi $10 \mathrm{~g} / \mathrm{L}$ peptone., $10 \mathrm{~g} / \mathrm{L}$ yeast extract., 0,001 g/L resazurin., 0,5 g/L Lsisteine- $\mathrm{HCl}$., 10 g/L glukosa. Medium dikondisikan pada pH 5 sebelum diinokulasikan dengan inokulum.

\section{- Prosedur Eksperimen}

Eksperimen dilakukan pada fermentor batch volume $100 \mathrm{~mL}$ dengan konsentrasi inokulum yang sudah diberi perlakuan $(5 \mathrm{~mL})$, substrat buah jeruk $15 \mathrm{~mL}$, dan $30 \mathrm{~mL}$ larutan stok nutrisi (Gambar 1). Volume kerja yang digunakan sebanyak $50 \mathrm{ml}$ dalam botol $100 \mathrm{ml}$ fermentor. Fermentor di inkubasi pada suhu optimal $37^{\circ} \mathrm{C}$ dan $\mathrm{pH}$ dikondisikan pada $\mathrm{pH} 5$.

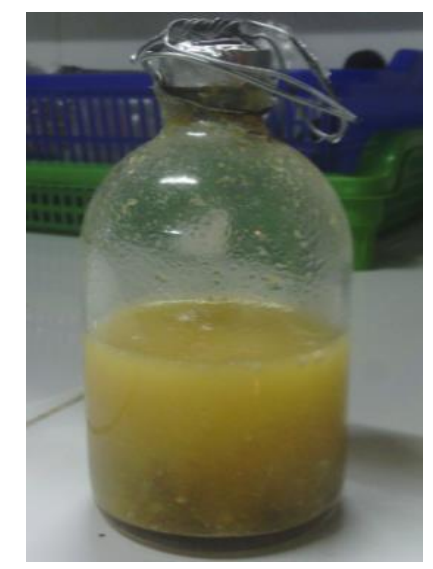

Gambar 1. Fermentor Berisi Limbah Buah Jeruk dan Mikrobia Campuran

\section{Hasil dan Pembahasan}

\subsection{Produksi Gas Hidrogen}

Dalam penelitian ini, dilakukan uji terhadap produksi gas hidrogen yang dihasilkan dari proses fermentasi gelap. Hasil dari produksi gas hidrogen dapat dilihat pada Gambar 2. Produksi gas hidrogen yang paling tinggi pada hari ke 7 yaitu $14 \mathrm{~mL} / \mathrm{L}$. Hal ini menunjukkan perbedaan pada penelitian yang dilakukan oleh Kharisma, 2015 yang menyatakan bahwa produksi hidrogen tertinggi dihasilkan pada hari pertama. Hal ini dikarenakan pada penelitian sebelumnya tidak menggunakan buffer untuk mempertahankan $\mathrm{pH}$ susbstrat, pada penelitian ini dilakukan penambahan buffer berupa kulit telur (Stefany, 2015) sehingga $\mathrm{pH}$ tiap fermentor tetap konstan yaitu berada pada rentang $\mathrm{pH} 4,5-5,5$. Hal ini sesuai dengan derajat keasaman optimum untuk menghasilkan gas $\mathrm{H}_{2}$ dari karbohidrat yaitu pada kisaran $\mathrm{pH}$ sekitar 4,5-6,0 (Wei dkk.,2010) 
karena itu pada rentang $\mathrm{pH}$ tersebut bakteri penghasil hidrogen membutuhkan waktu yang cukup lama sehingga produksi gas hidrogen mengalami perlambatan.

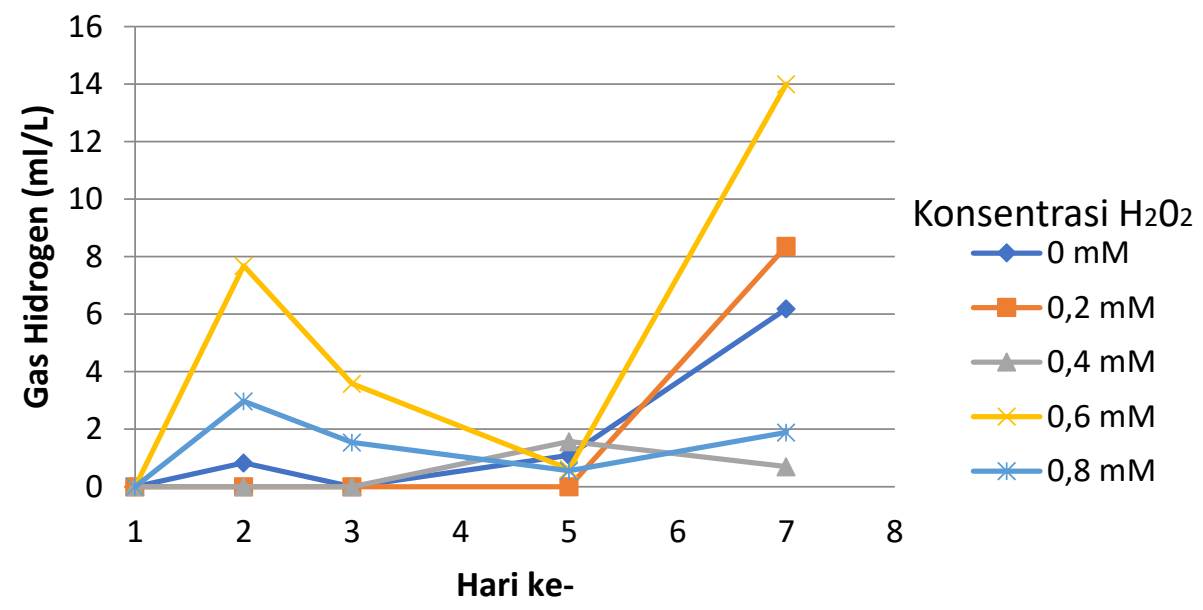

Gambar 2. Gas hidrogen yang dihasilkan selama proses fermentasi oleh mikroba campuran

\subsection{Pengaruh Penambahan $\mathrm{H}_{2} \mathrm{O}_{2}$ Pada Gas Hidrogen}

Dalam penelitian ini, dilakukan penambahan $\mathrm{H}_{2} \mathrm{O}_{2}$ pada gas hidrogen. Berdasarkan hasil analisa Gas Chromatography (GC), dapat diketahui produksi gas hidrogen selama 7 hari yang dapat dilihat pada Tabel 1.

Tabel 1. Produksi gas yang dihasilkan dalam proses fermentasi selama 7 hari menggunakan mikroba campuran

\begin{tabular}{ccc}
\hline $\begin{array}{c}\text { Konsentrasi } \\
\mathbf{H}_{2} \mathbf{O}_{2}\end{array}$ & $\begin{array}{c}\text { Total Gas } \\
(\mathbf{m L} / \mathbf{L})\end{array}$ & $\begin{array}{c}\text { Yield H2 } \\
(\mathbf{m L . g} / \mathbf{V S})\end{array}$ \\
\hline $0 \mathrm{mM}$ & 8,116 & 112,97 \\
$0,2 \mathrm{mM}$ & 8,363 & 160,83 \\
$0,4 \mathrm{mM}$ & 2,269 & 121,99 \\
$0,6 \mathrm{mM}$ & $\mathbf{2 5 , 8 7 7}$ & $\mathbf{8 0 1 , 1 4}$ \\
$0,8 \mathrm{mM}$ & 6,963 & 440,7 \\
\hline
\end{tabular}

Dari hasil yang telah diperoleh, dapat diketahui bahwa penambahan konsentrasi $\mathrm{H}_{2} \mathrm{O}_{2}$ cukup memberikan nilai yang signifikan terhadap produksi gas hidrogen yaitu pada konsentrasi 0,6 dan 0,8 mM yang menghasilkan yield hidrogen 801,14 dan 440,7 mL.g/VS. Hal ini menunjukkan bahwa pada pemberian $\mathrm{H}_{2} \mathrm{O}_{2}$ pada kadar tertentu dapat memberikan nilai yang baik dalam 
pembentukan gas hidrogen, akan tetapi jika terlalu tinggi maka akan mengakibatkan penurunan jumlah gas hidrogen.

\subsection{Pengaruh Penambahan $\mathrm{H}_{2} \mathrm{O}_{2}$ Pada Asam Organik Terhadap Produksi Gas Hidrogen}

Penyebab produksi gas hidrogen yang fluktuatif dapat diidentifikasi dari hubungan antara produksi gas hidrogen dan asam-asam organik. Pada penelitian ini asam organik yang memiliki perbedaan yang cukup signifikan yaitu antara produksi gas hidrogen dengan produksi asam asetat.. Dari hasil yang didapat, diketahui bahwa produksi gas hidrogen yang tertinggi berasal dari pemberian konsentrasi $\mathrm{H}_{2} \mathrm{O}_{2}$ dengan konsetrasi $0,6 \mathrm{mM}$ yang memiliki hasil asam asetat yang rendah. Hubungan antara produksi gas hidrogen dan produksi asetat pada konsentrasi 0,6 $\mathrm{mM}$ dapat dilihat pada Gambar 3.

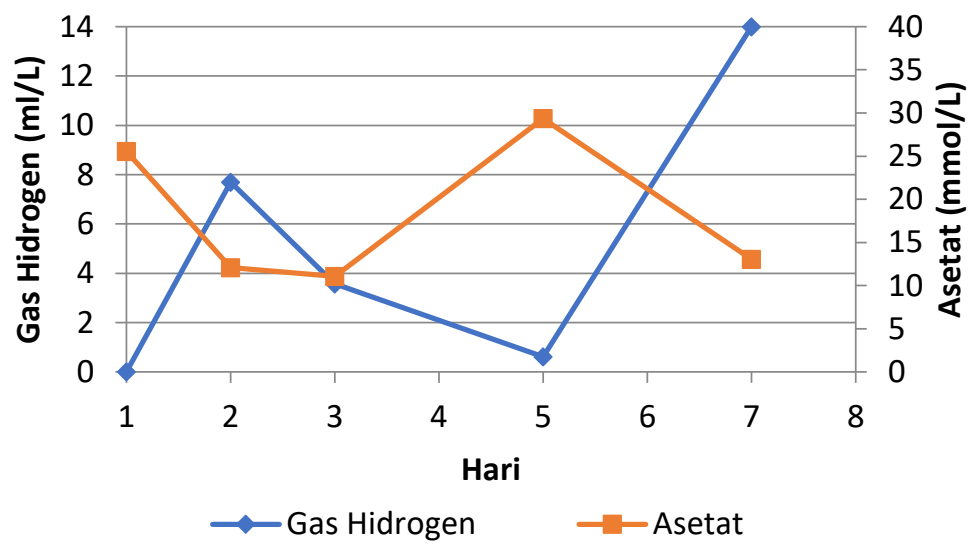

Gambar 3. Hubungan antara produksi gas hidrogen dan produksi asetat pada konsentrasi 0,6 Mm

Dari Gambar 3 di atas, dapat diketahui bahwa asetat memiliki pengaruh terhadap produksi gas hidrogen yang mana produksi gas hidrogen akan meningkat jika produksi asetat kecil. Hal ini sesuai dengan penelitian Ren dkk (2006) yang menyatakan bahwa asetat merupakan salah satu senyawa yang dapat menghambat produksi gas hidrogen.

\section{Kesimpulan}

Penambahan $\mathrm{H}_{2} \mathrm{O}_{2}$ pada limbah buah jeruk oleh mikroba dari digester biogas dapat meningkatkan yield gas hidrogen yaitu sebesar $801,14 \mathrm{~mL} . \mathrm{g} / \mathrm{VS}$ dan konsentrasi optimum penambahan $\mathrm{H}_{2} \mathrm{O}_{2}$ yaitu pada konsentrasi $0,6 \mathrm{mM}\left(30 \mu \mathrm{l} \mathrm{H}_{2} \mathrm{O}_{2} / 15 \mathrm{ml}\right.$ limbah buah jeruk), sedangkan pada konsentrasi 
0,8 $\mathrm{mM}\left(40 \mu \mathrm{H} \mathrm{H}_{2} \mathrm{O}_{2} / 15 \mathrm{ml}\right.$ limbah buah jeruk) terjadi penurunan produksi gas hidrogen, sehingga semakin tinggi penambahan konsentrasi $\mathrm{H}_{2} \mathrm{O}_{2}$ akan menurunkan produksi gas hidrogen. Produksi gas hidrogen yang paling tinggi yaitu pada hari ke-7, sehingga perlu dilakukan penelitian lebih lanjut dengan variasi hari yang lebih lama dan Perlu adanya penelitian lebih lanjut untuk dapat menghilangkan atau mengurangi kadar limonen yang dapat menghambat produksi gas hidrogen.

\section{DAFTAR PUSTAKA}

Chang, R.C dan Lin, Y.C. (2004). Fermentative Hydrogen Production at Ambient Temperature. International Journal Hydrogen Energy, 29: 715-720

Husin, Amir., Sarto., Syamsiah, Siti dan Parasetyo, Imam. (2014). Produksi Biohidrogen dari Hidrolisat Ampas Tahu Secara Fermentasi Anaerob Menggunakan Kultur Campuran, Reaktor, 15(2) : 87-96.

Kim, J.0., Kim, Y.H., Yeom, S. H., Song, B.K dan Kim, I.H. (2006). Enhancing Continuous Hydrogen Gas Production by the Addition of Nitrate Into an Anaerobic Reactor. Process Biochem, 41:1208-1212

Das, Debratas dan T. Nejat Veziroglu. (2008). Advance in Biological Hydrogen Production Processes. International Journal of Hydrogen Energy, 33 : 6046-6057

Elsharnouby, O., Hafez, H. Nakhla, G dan El Naggar, MH. (2013). A Critical Literature Review on Biohydrogen Production by Pure Cultures. Internation Journal Hydrogen Energy 38 : 4945-4966

Kim, M.S dan Lee, D. Y. (2010). Fermentative Hydrogen Production from Tofu Processing Waste and Anaerobic Digester Sludge Using Microbial Consorcium, Bioresource Technology, 101:S48-S52

Kapdan, I. K dan F. Kargi. (2006). Bio-hydrogen Production from Waste Materials. Enzyme and Microbial Technology, 38:569-582

Kharisma, Agung Dian. (2015). Pengaruh Hidrogen Peroksida terhadap Produksi Hidrogen Dari Limbah Buah Melon: Cucumis Melo L.) Oleh Mikroba Digester Biogas. Tesis, Pascasarjana Universitas Gadjah Mada 
Stefany, Windy. (2015). Produksi Biogas Dari Campuran Sampah Buah Dengan Perlakuan Awal Distilasi Uap. Tesis, Pascasarjana Universitas Gadjah Mada

Wei, Juan., Liu, Zuo-Tao dan Zhang, Xin. (2010). Biohydrogen Production from Starch Wastewater and Application in Fuel Cell. Int J Hydrogen Energy, 35(29): 49-52

Ren, N dan Gong, M L.(2006). Characteristics and Operation of Enchanced Continuous BioHydrogen Production Reactor Using Support Carrier, NCBI Journal 9 